\title{
Powieść i mnóstwo wątpliwości
}

\section{The Novel and a Whole Lot of Uncertainty}

Czytając szkic Thomasa Pavla, miałem niestety w pamięci niezrównany esej Milana Kundery Sztuka powieści, pełen żarliwej wiary i nadziei, a także miłości do gatunku, któremu autor Nieznośnej lekkości bytu poświęcił całe życie. Porównania są w takiej sytuacji nieuchronne i oczywiście niekorzystne, a nawet miażdżące dla rumuńskiego badacza.

Podczas gdy Kundera przekonuje nas, że powieść to bezcenne narzędzie poznania, klucz do wszystkich tajemnic, o których rozmyślają filozofowie od Platona do Martina Heideggera (a wraz z nimi cała myśląca część ludzkości), Pavel proponuje nam jakiś mało przekonujący i abstrakcyjny schemat. Kundera dowodzi konsekwentnie, że powieść to wynalazek cywilizacji zachodniej, towarzyszący czterem wiekom dziejów nowożytnych. Można się z tym nie zgadzać, ale trudno lekceważyć przemawiające za taką koncepcją argumenty. Tymczasem dla Pavla początki powieści toną gdzieś w mrokach starożytności. Nie mam nic przeciwko takim próbom, powinny one być jednak nieco staranniej uzasadnione. Jeśli cofamy się już do prehistorii (a na pewno można w ten sposób opisać dzieje gatunku), to musimy zestawiać powieść nie tylko z eposem, ale także z mitem. Akurat tej perspektywy wyraźnie tu brakuje.

Nie jest również oczywiste, że powieść musi się rozpoczynać w starożytnej Grecji - tak, istotnie, wiele gatunków wywodzi swój żywot ze świata literatury antycznej, ale przecież nie wszystkie. Prawdę mówiąc, związek owych dokonań pisarzy starożytnych z tym, co dziś uważamy za powieść, wydaje mi się dość problematyczny. Europocentryzm Pavla nie pozwala również na odniesienia - dziś już chyba konieczne - do literatur orientalnych. Wiadomo przecież, że powieść chińska czy japońska, nie mówiąc już o narracjach arabskich albo indyjskich, to też wyzwanie dla badacza literatury. A może powieść zrodziła się w najbardziej odległej starożytności, nad brzegami Nilu?

Oczywiście, są to tylko efektowne hipotezy, które szanujący się badacz akademicki pozostawia za drzwiami swej pracowni. Sądzę jednak, że kiedy 
już przystępuje do pisania (i przekonywania czytelnika, że ma rację), powinien wiedzieć na pewno, czym jest powieść. To zadanie bardzo trudne, skoro w wieku XX granice niemal wszystkich uprawianych jeszcze gatunków uległy poszerzeniu, a niekiedy wręcz zatarciu. Mimo wszystko pisząc teorię czy historię powieści, musimy jasno zdać sobie sprawę, które teksty są jeszcze powieściami, a które nimi mimo wszystko nie są. A jeśli to zadanie okaże się niewykonalne, to przynajmniej musimy dążyć do zachowania jakiejś prowizorycznej bodaj hierarchii, z konieczności zapewne subiektywnej.

Szkic Pavla zaczyna się bardzo interesująco, lecz w miarę lektury ogarniają nas coraz większe wątpliwości. Dotyczą one również wspomnianej wyżej hierarchii, a raczej jej braku. Naprawdę trudno mi zaakceptować model powieści europejskiej, w której tak ważne miejsce zajmują romans pasterski i opowieści łotrzykowskie, a Flaubertowi przypada tak marginalna rola! Nie mam nic przeciwko temu, by w poszukiwaniu korzeni cofać się do literackiej prehistorii, ale przecież niepodobna zlekceważyć dokonującego się na naszych oczach procesu, w którego następstwie pewni autorzy po prostu przestają być czytani, a inni, za życia cenieni mniej, okazują się dla potomnych znacznie bardziej inspirujący. Thomas Pavel jakby tego nie zauważał, w jego modelu nie ma miejsca na perspektywę dwudziestowieczną i późniejszą. Ten rozdźwięk czuje chyba sam badacz, dokonując w pewnym momencie trochę karkołomnego podziału na „powieść” i „powieść nowożytną”, lecz nie mamy całkowitej pewności, czy - tak jak przekonuje nas choćby Kundera - nie są to przypadkiem synonimy.

Każdy miłośnik powieści, zwłaszcza obdarzony wyobraźnią literacką, chętnie przyzna, że to niemożliwe, by ludzkość mogła przez tyle wieków obywać się bez powieści. Dla fanatyków gatunku powieść jest równie ważna jak koło, ogień, wino, prawo... Może więc mieli rację twórcy serii wydawniczej sprzed lat, prezentującej klasyczną powieść, włączając do zestawu arcydzieł również pozycje uważane na ogół za poematy - Odyseje w przekładzie prozą Jana Parandowskiego oraz Tristana i Izoldę w tłumaczeniu Tadeusza Boya-Żeleńskiego? Można zaczać od Homera albo Gilgamesza, można od Daniela Defoe i Jonathana Swifta, lecz budując model powieści europejskiej, nie można chyba lekceważyć istniejącego stanu rzeczy. To nie Samuel Richardson czy Jean Jacques Rousseau zdecydowali o oszałamiającym sukcesie powieści w XIX i XX wieku. I to nie oni należą do pisarzy, których dzieła wyznaczają dziś możliwości gatunku.

Pisanie historii powieści w porządku chronologicznym to pomysł skądinąd naturalny i trudno sobie wyobrazić, by rekonstruując (albo tworząc) jakąkolwiek tego typu pracę, nie zacząć „od początku”. A jednak można też inaczej! W XX wieku nawet przeciętny prozaik pozbawiony ambicji eksperymentatora wiedział doskonale, że narrację rozpocząć można również „od końca”. W szkicu Pavla respekt dla chronologii przynosi bardzo ograniczone korzyści, skoro najważniejsze osiągnięcia powieści europejskiej (Gustave Flaubert, Fiodor Dostojewski, Henry James, Marcel Proust, James Joyce) okazują się jakimiś niezupełnie zrozumiałymi kontynuacjami wcześniejszych dokonań. Być może 
znacznie łatwiejsza i bardziej owocna byłaby droga odwrotna - od współczesności w głąb minionych stuleci, od Joyce'a do Laurence'a Sterne'a i Homera, od Franza Kafki do Jonathana Swifta i Księgi Hioba?

Do sprzeciwu skłaniają zwłaszcza liczne generalizacje, bez których autor tak pomyślanego szkicu nie może się, rzecz jasna, obejść. Uogólnienia są niebezpieczne nawet wówczas, gdy piszemy o jednym, zdawałoby się dobrze nam znanym utworze. Cóż dopiero, gdy mówić mamy o kosmosie powieści (choćby i ograniczonym do literatury zachodniej)! Tu po prostu stąpamy po polu minowym, bo zawsze znajdzie się jakiś erudyta, który wykrzyknie, że nie mamy racji, i wskaże przykład utworu wykraczającego poza konwencje. Skoro powieść od ponad stu lat przekracza wszelkie możliwe granice, to warto byłoby zachować większą ostrożność. No, ale trudno umieszczać w każdym zdaniu zastrzeżenie, że na pewno jakieś wyjątki istnieją, a budując nasz efektowny model chwilowo o nich zapominamy.

Już na pierwszej stronie omawianego szkicu przeczytałem, że „powieść tradycyjnie koncentrowała się na miłości i łączeniu się ludzi w pary”. Kiedyś zastanawiałem się całkiem poważnie, czy zdarzają się wybitne powieści pozbawione w ogóle wątków miłosnych, ewentualnie takie, w których flirty, romanse, małżeństwa nie odgrywają poważniejszej roli. Oczywiście - przypomnijcie sobie choćby Przypadki Robinsona Crusoe (tego tytułu Pavel przezornie nie wymienia). A co do słuszności zacytowanego zdania - skreślmy „miłości i łączeniu się ludzi w pary” i wstawmy na przykład „zbadaniu relacji między człowiekiem a światem”, ,analizie sytuacji egzystencjalnej jednostki”, ,ukazywaniu dobra i zła” itd. Po takiej zmianie zdanie wciąż pozostaje sensowne! I myślowo równie jałowe...

Czy zatem w ogóle można i czy warto pisać historię powieści? I jak to robić? Na pewno z większym rozmachem, co nie musi oznaczać: z większa liczbą nazwisk i tytułów. Na pewno - bardziej wnikliwie, choć rozumiem doskonale, że lapidarność pogłębionej refleksji nie służy, a każda synteza wcześniej czy później zamienia się w kolekcję (o ile nie w katalog).

Mimo wszystko dyskutując o słuszności modelu powieści zbudowanego przez rumuńskiego badacza, nie sposób chyba przejść do porządku dziennego nad tworzącymi go elementami, to znaczy pojedynczymi, z konieczności wyrwanymi z kontekstu opiniami składającymi się na całościową konstrukcję. Jeśli nie mają one pokrycia w rzeczywistości, jeśli graniczą z niedopuszczalnym uproszczeniem, to musimy ten fakt wziąć pod uwagę, oceniając ostateczne konkluzje. Trudno mi zgodzić się z tezą Pavla, iż istota prozy Jamesa polega na oddzieleniu „moralnego sceptycyzmu od tradycji komicznej”, bo takie uogólnienie okazuje się niewiele znaczącym ogólnikiem - zwłaszcza dziś, gdy twórczość amerykańskiego pisarza znów lśni pełnym blaskiem, jest czytana, podziwiana i analizowana w tylu przyczynkach oraz monografiach. Interpretacja powieści Dostojewskiego stanowi przekonujący dokument, że autor szkicu na pewno specjalistą w zakresie prozy rosyjskiej nie jest. Niestety, nawet Proust został ledwie muśnięty, Hermann Broch przeoczony, Robert Musil 
potraktowany marginalnie. Z niedowierzaniem przeczytałem, że William Faulkner „nie przedstawia konfliktów między jednostkami a normami moralnymi”. Czyżby? Przeczytajcie choćby Absalomie, Absalomie!

Kiedy wkraczamy w obszar drugiej połowy XX wieku, interpretację zastępuje enumeracja - może inaczej się nie da, może inaczej nie można? W epoce mediów i reklamy każdy autor (wyłączając dostarczycieli popularnych czytadeł, których Pavel słusznie skazuje na niepamięć) wydaje się monadą. Każdy jest inny, każdy jest „osobny”. Ale jeśli coś go łączy z innymi, to na pewno nie etykietka „postmodernizmu”, tak dziś kontrowersyjna, że nie określająca już niczego.

I czego można dowieść, wyliczając po prostu trzy czy cztery tuziny nazwisk, najzupełniej przypadkowo dobranych (Nagroda Nobla stanowi tu jakiś argument, ale jakże skromny!)? I o czym przekonać czytelników, gdy pomija się kompletnie dorobek takich autorów, jak Italo Calvino, Heimito von Doderer, Günter Grass, Hermann Hesse, José Lezama Lima, Samuel Beckett, Michał Bułhakow, wreszcie - oczom własnym nie wierzę - Vladimir Nabokov... Może to wcale nie dziwne, skoro wcześniej Charles Dickens został zbyty półzdaniową wzmianką, a Herman Melville nie pojawił się w ogóle! Joris Karl Huysmans to nie tylko autor $N a$ wspak, ale także prekursor powieści-eseju (Katedra najlepszym przykładem). A Joseph Conrad? Czyżby już nieważny? Przecież ciągle czyta się jego powieści i komentuje, przynajmniej w świecie anglosaskim. Na ciepłe słówko o Juliuszu Vernie wcale nie liczyłem, choć jest to ciągle najpopularniejszy i najczęściej tłumaczony powieściopisarz wszystkich czasów.

Skoro autor Tajemniczej wyspy nie zasłużył w minimalnym choćby stopniu na obecność, cóż powiemy o kwestii „Thomas Pavel a sprawa polska”? Chyba tylko tyle, że podobne zagadnienie niestety nie istnieje. Można by co najwyżej zastanowić się, dlaczego.

Jak łatwo zauważyć, literatura polska (także powieść) jest oczywiście tłumaczona na niemal wszystkie języki świata. Jest tłumaczona, ale niestety nie jest czytana. Pod tym względem autor szkicu nie jest, jak się zdaje, żadnym wyjątkiem. Wybaczymy mu chętnie nieznajomość Pana Podstolego oraz Mikotaja Doświadczyńskiego, bo iluż polonistów przeczytało rzetelnie te nie dla wszystkich porywające powieści? Wydawałoby się jednak, że Jana Potockiego mógłby mimo wszystko znać, bo Rękopis znaleziony $w$ Saragossie to przecież arcydzieło niezwykłe i bardzo europejskie. Nieobecność polskiego wieku XIX na pewno nas zaboli. No cóż, nie udało się nam wylansować Lalki, co powinno być proste ze względu na walory artystyczne, nie włożyliśmy serca w utrzymanie popularności Quo vadis. Z wieku XX też nie ma nikogo. A Witold Gombrowicz, a Stanisław Lem? Powieść eksperymentująca nie jest mocną stroną autora szkicu, a fantastykę naukowa wyłącza on poza obręb zainteresowania, co dziś graniczy z niejakim anachronizmem.

Trudno, nie ma wyjścia: historii polskiej powieści nikt nam nie napisze. Musimy to zrobić sami, o ile chcemy, o ile potrafimy, o ile warto. 
Padające w zakończeniu kwestionariusza pytanie o przyszłość powieści nie wymaga właściwie odpowiedzi, bo nikt nie ma pojęcia, co nas jeszcze czeka $\mathrm{w}$ epoce internetu, gier komputerowych i bezkresnych seriali telewizyjnych. Tak czy inaczej, pytanie to należy stawiać nieustannie, bo skłania nas ono do jakiegoś prowizorycznego przynajmniej bilansu. Musimy zdawać sobie sprawę, czym jest dziś powieść, komu jeszcze jest potrzebna, gdy włóczy się po świecie tylu potencjalnych, ale niezdecydowanych czytelników i wielu niechętnych powieściopisarzom wydawców.

Wypowiadając tyle wątpliwości (mówiąc dokładniej: prawie same wątpliwości), pod jednym względem zgadzam się z Thomasem Pavlem. Nie myli on - jak czyni większość krytyków literackich - popularności powieści z jej żywotnością. Nie zwraca uwagi na listy czytelniczych bestsellerów, choć studiuje listę nagrodzonych noblistów. W gruncie rzeczy jednak z punktu widzenia historyka powieści fakt, że mierny pisarz jest czytany chętniej niż autor arcydzieł, nie ma żadnego znaczenia. Ale jeśli wybitny, zdaniem badacza, twórca nie jest czytany w ogóle, nie inspiruje, a jego obecność ogranicza się jedynie do słowników i encyklopedii? Czy kanonu powieści (a zarazem żywotności gatunku) nie określa raczej poczytność niż model budowany w zaciszu pracowni?

W połowie XX wieku mówiono o „kryzysie powieści”, którego tak naprawdę nie było. Odpowiedzią na wyczerpanie gatunku miała być „nowa powieść”, zwana też „antypowieścią”, pozbawiona bohatera i fabuły, mało efektowna w lekturze. A tymczasem na innym kontynencie dojrzewał już latynoski boom, czytano z zapałem Sto lat samotności, Grę w klasy, O bohaterach i grobach, Raj...

Lecz co to właściwie znaczy, czy powieść przetrwa?

Po pierwsze - jestem pewien, że ciągle znajdą się (na szczęście) pisarze, dla których powieść nie będzie ani przepustką do literackich nagród, ani gwarancją sukcesu komercyjnego, lecz narzędziem poznania, co najmniej równie doskonałym jak traktat filozoficzny czy medytacja w duchu Martina Heideggera.

Po drugie - myślę, że nie zabraknie czytelników, którym w świecie opanowanym przez telewizję i internet czegoś jeszcze będzie brakować, mianowicie czegoś, co stanowi istotę powieści i co jest nieprzeniknioną zagadką (może rozwiążemy ją na końcu tego tekstu).

Po trzecie - mam nadzieję, że znajdą się wydawcy, którzy potrafią dostrzec coś więcej niż ocean czytadeł, wtórnych i źle opowiedzianych, ale dobrze reklamowanych, że zaryzykują rynkową klęskę, umożliwiając nawet nielicznym czytelnikom i autorom tajemną nić porozumienia.

Po czwarte - myślę, że powieść jest książką, co znaczy mniej więcej tyle, że duchowy skarb zamknięty został $\mathrm{w}$ formę takiego a nie innego przedmiotu. Uwierzmy, że doskonałego, i nie zmieniajmy tego. Dodam, że mam w komputerze i na nośnikach elektronicznych kilka tysięcy plików. Czytam nieustannie z ekranu i nie jest prawdą twierdzenie pewnej młodej edytorki, że nie widziałem 
nigdy na oczy wordowskiego pliku, nie korzystam z dobrodziejstw elektryczności, a pranie noszę ciągle do rzeki. Owszem, potrafię używać monitora i tabletu, ale mimo wszystko powieści wolę czytać metodą tradycyjną.

Po piąte - cóż, chyba nikt na pytanie o żywotność powieści nie odpowiedział bardziej przekonywająco niż zlekceważony przez Pavla autor Niewinnych, Lunatyków i Śmierci Wergilego. Na pytanie o żywotność gatunku Hermann Broch odpowiedział, że jedyną i całkowicie wystarczającą racją powieści jest odkrywanie tego, co wyłącznie powieść odkryć potrafi. Tylko w ten sposób powieść usprawiedliwia swe istnienie i tylko z tej przyczyny może liczyć na nieśmiertelność. 